\title{
Metastatic Clear Cell Renal Cell Carcinoma
}

National Cancer Institute

\section{Source}

National Cancer Institute. Metastatic Clear Cell Renal Cell Carcinoma. NCI Thesaurus.

Code C162768.

A clear cell renal cell carcinoma that has spread from its original site of growth to other anatomic sites. 